\title{
Information Asymmetries And Closed-End Funds
}

\author{
Eric Higgins, Kansas State University, USA \\ Shawn Howton, Villanova University, USA \\ Shelly Howton, Villanova University, USA \\ Sophie Xiaofei Kong, Western Washington University, USA
}

\begin{abstract}
We examine the degree to which information asymmetries play a role in the closed-end fund seasoned offerings and introduce a new explanation for why funds with low information asymmetry also choose to issue. Interpreting turnover ratio as a proxy for information asymmetry, we test for differences in turnover across fund types and find that equity and international fund issuers generate significantly higher turnover than debt and domestic fund issuers respectively. We then investigate the motives for issuing funds with low information asymmetry and discover that they are good asset market timers, i.e. issue when underlying asset markets are relatively underpriced. By timing asset markets, such funds generate better long-run returns and maximize the interests of long-term investors.
\end{abstract}

Keywords: Information asymmetry; closed-end funds; seasoned offerings; turnover ratio

\section{INTRODUCTION}<smiles>[C]1C=CCCC1</smiles>

everal studies have examined the market response to seasoned equity offerings (SEOs) made by industrial firms. Ritter (1991) and Loughran and Ritter (1995) find that firms offering either IPOs or SEOs significantly underperform nonissuing firms over two to five years following the issue. White and Lusztig (1980), Hansen (1988), Kothare (1997) and Eckbo and Masulis (1992) all find evidence of significantly negative announcement day returns associated with rights offerings made by US industrial firms. One of the common explanations for the negative market reaction to the announcement of a seasoned offering is the information asymmetry model developed by Myers and Majluf (1984). Given the difficulty in valuing the assets of the firm, investors have no accurate way of discerning the true value of the firm. Thus, based on the Myers and Majluf model, investors assume that managers are more likely to issue equity when they believe, based on their superior information of their firm, that the market is overvaluing their stock. Therefore, information asymmetries between shareholders and managers drive the negative market reaction to a seasoned offering.

Closed-end funds provide a better sample to test information asymmetry hypothesis. First, by holding marketable securities, closed-end funds have less of an information asymmetry problem than industrial firms. Second, some closed-end funds suffer more information asymmetry than others due to various difficulties in pricing different security instruments. Generally, debt and domestic securities are easier to price than equity and international securities.

Similar to industrial firms, SEOs of closed-end funds also receive negative announcement day returns. This has been documented by Akhigbe and Madura (2001) and Higgins, Howton and Howton (2003). In addition, Higgins, Howton and Howton (2003) also find evidence that funds with relatively high information asymmetry i.e. equity and international funds) have more negative announcement day returns than funds with low information asymmetry (i.e. debt and domestic funds). Such evidence provides at least partial support for the presence of information asymmetry and drives the need to discover to what degree information asymmetry plays a role in closed-end funds SEOs. 
In this paper, we first introduce a new proxy for information asymmetry, turnover ratio, to verify the presence of information asymmetry. Higher turnover ratio is generally associated with greater information asymmetry. We examine changes in turnover ratio from pre-offering to post-offering period. Next, we investigate the motives for funds with low information asymmetry to issue seasoned offerings. By examining the trends in underlying asset markets, we find supportive evidence that funds with few information asymmetries could issue to take advantage of favorable asset market conditions.

The major contribution of this paper is two-fold. First, we test the power of an alternative proxy for information asymmetry within the sample of closed-end fund issuers. Second, we present a new explanation for why low information asymmetry funds also issue. In previous work on seasoned offerings, equity market timing based on information asymmetry is often used to explain the post-offering performance. This fails to justify why some fund issuers have positive post-offering returns while others suffer negative returns. Apparently, funds with positive longrun performance are not timing the equity market. Asset market timing is proposed as an equally important tool available to fund managers to exploit pricing inefficiencies in the underlying asset markets. Thus, funds can time their offerings when underlying asset markets are underpriced and thus capitalize on favorable market conditions when asset markets are priced correctly.

\section{LITERATURE REVIEW AND HYPOTHESES}

There is not complete agreement as to the cause of the negative market responses or the poor long-run performance around seasoned offerings by closed-end funds. Some studies attribute the negative market reaction at announcement to governance or agency cost related factors. Akhigbe and Madura (2001) find that the abnormal returns for closed-end fund seasoned offerings are inversely related to the expense ratio of the fund. Khorana, Wahal and Zenner (2002) find that the degree to which closed-end fund premiums decline around rights offerings is directly related to the fund's advisor fees and the fund's affiliation with the broker-dealer used in the rights offering. However, the evidence in Higgins, Howton and Howton (2002) and Higgins, Howton and Howton (2003) make it rather difficult to completely rule out the relation between information asymmetries and the negative reaction for closed-end funds. Higgins, Howton and Howton (2002) find that closed-end fund seasoned offerings cause a significant and negative reaction across all non-issuing closed-end funds within the same sector. It is difficult to justify that governance or agency factors could generate this spill-over effect to non-issuers. Therefore, there exists a need to reevaluate the information asymmetry model as a possible explanation for the documented market reaction to closed-end fund offerings.

In addition to supporting the presence of information asymmetry in closed-end funds SEOs, Higgins, Howton and Howton (2003) document less long-term underperformance for domestic and debt relative to international and equity funds. Since funds types can proxy for information asymmetry due to the varying pricing difficulty of securities, they conclude that the size of negative market reaction to closed-end funds issuers are directly related to the degree of information asymmetry of the funds.

To further determine the role that information asymmetries play in both the initial market reaction and the long-term performance around fund SEOs, we use turnover ratio for the fund. Kyle (1985) and Llorente, Michaely, Saar and Wang (2002) find evidence that the turnover ratio is directly related to the degree of information asymmetry that exists for a firm's equity. Thus we expect to find significant difference in turnover ratios across fund types as well as significant difference in turnover ratios between issuing and non-issuing funds.

Then, what motivates funds with low information asymmetry to issue shares? Besides timing the equity market, fund managers have incentives to time the underlying asset markets. Instead of issuing shares when their funds trade at a significant premium to true value, they may actually choose to issue shares when asset prices are low. Doing so maximizes the long-run value of the fund as opposed to maximizing the short-term value to existing shareholders. We hypothesize 1) funds with low information asymmetry issue shares when asset markets are undervalued; 2) if funds issue to time asset markets, they are more likely to generate better long-run returns; 3 ) funds who time asset markets instead of equity markets are more likely to attract long-horizon investors. 
To verify asset market timing, we follow the directions in Schultz (2003). If fund managers issue shares to capitalize on favorable opportunities in the underlying asset markets, we would expect to observe positive long-run stock performance as the fund ultimately reflects the performance of its underlying assets. Thus, we would anticipate that offerings by funds with fewer information asymmetries are preceded by worse than average asset markets allowing them to capitalize on potentially undervalued asset markets. We obtain a relevant market index for each issuing fund based on its investment objective and measure how asset markets move around the fund issuance. A proportion test is also used to compare the percentage of asset market timers across fund types.

To verify whether issuing funds with low information asymmetry are more likely to attract long-horizon investors, we use the measure of turnover ratio to proxy for investor trading horizon. Froot, Perold and Stein (1992) state that higher turnover ratio is associated with shorter investor trading horizon. Subsequent research by Wahal and McConnell (2000) shows that investor trading horizon also influences managerial decisions regarding future investment. Therefore, managers at firms with higher trading volume may act myopic to cater to short-term investors. We expect that funds with low information asymmetry that issue to time asset markets cater to long-term investors, and thus are associated with lower turnover ratio.

\section{DATA}

We obtain all seasoned offerings made by closed-end funds from the Securities Data Corporation (SDC) database between 1980 and 2004. We require that the funds have returns and volumes available on the Center for Research in Security Prices (CRSP) files at the time of the offering. Our sample contains 135 seasoned offerings. There are 29 public underwritten offers and 106 rights offers in the final sample. Net asset values and market values six months prior to issuance, on the closest date to issuance, and six months after issuance are collected from the Wall Street Journal. This information allows us to calculate premiums/discounts around the time of the offering. We classify each of the issuing funds in our sample into groups based on the primary assets in which the fund invests using annual reports for the funds to determine which category is most relevant. The funds are classified as either debt or equity funds and also as either domestic or international funds. Each of these categories of funds determines the sectors that we use to form the same-sector groups of non-issuing match funds. Using the fund categorizations in the Wall Street Journal, we identify all similarly categorized funds on the closest report date prior to the offering for each sample fund and identify this set as our matching funds.

Following Hong, Lim and Stein (2000), we define the turnover ratio as the average trading volume scaled by the number of shares outstanding. The trading volume and shares outstanding are obtained from the CRSP database, and the turnover ratio is estimated as a monthly average over the 6-month period prior to and after the offering month.

\section{EMPIRICAL ANALYSIS}

\section{Turnover Ratio and Fund Types}

Table 1 contains the average turnover ratio for issuing and matching funds categorized by asset class (international, domestic, equity and debt). Equity and international funds have significantly higher turnover ratio than debt and domestic funds, respectively. This increased trading is observed in both the pre- and post-offering sixmonth period for both our sample funds and the matching funds. Using turnover ratio as a proxy for information asymmetry, we conclude that international and equity funds have a higher degree of information asymmetry than domestic and debt funds, respectively. In unpublished tables, we also confirm that this degree of information asymmetry is consistent with the differences across fund types that we observe in both short-run and long-run abnormal returns.

In Panel A, we also find that debt and domestic issuers experience a significant drop in turnover across the offering period while the change for equity and international issuers is insignificant. We do not observe this same pattern in Panel B for the matching funds. We interpret the decline in turnover for the domestic and debt funds as a reduction in information asymmetries. Investors of debt and domestic funds may have received assurance over the one-year period around the offering. Such assurance can be explained by the realization that such funds are timing 
undervalued asset markets to maximize shareholder interests. We will examine whether debt and domestic funds are indeed market timers later.

Table 1: Changes in Turnover Ratio across Fund Categories for Issuing and Match Funds

Panel A: Issuing Funds

\begin{tabular}{|c|c|c|c|c|c|c|c|c|c|c|}
\hline & \multicolumn{2}{|c|}{ Equity=92 } & \multicolumn{2}{c|}{ Debt=42 } & & \multicolumn{2}{c|}{ International=75 } & \multicolumn{2}{c|}{ Domestic=59 } & \multicolumn{1}{|c|}{ D2 } \\
\hline Turnover (\%) & Mean & Median & $\underline{\text { Mean }}$ & $\underline{\text { Median }}$ & t-stat & Mean & $\underline{\text { Median }}$ & $\underline{\text { Mean }}$ & $\underline{\text { Median }}$ & t-stat \\
\hline Pre-offering & 11.20 & 9.27 & 5.40 & 5.06 & $6.54 *$ & 12.79 & 10.77 & 5.05 & 4.82 & $8.52^{*}$ \\
\hline Post-offering & 10.51 & 8.23 & 3.74 & 3.30 & $7.19 *$ & 12.13 & 10.14 & 3.63 & 3.37 & $8.3 *$ \\
\hline Changes & -0.69 & -0.79 & -1.66 & -1.26 & & -0.66 & -0.90 & -1.41 & -1.15 & \\
\hline t-statistic & -0.75 & & $-6.46^{*}$ & & & -0.59 & & $-6.64 *$ & & \\
\hline
\end{tabular}

Panel B: Match Funds

\begin{tabular}{|c|c|c|c|c|c|c|c|c|c|c|}
\hline & \multicolumn{2}{|c|}{ Equity=2941 } & \multicolumn{2}{|c|}{ Debt=802 } & \multirow[b]{2}{*}{ t-stat } & \multicolumn{2}{|c|}{ International=2621 } & \multicolumn{2}{|c|}{ Domestic=1122 } & \multirow[b]{2}{*}{ t-stat } \\
\hline Turnover (\%) & Mean & Median & Mean & Median & & Mean & Median & Mean & Median & \\
\hline Pre-offering & 9.46 & 7.66 & 4.49 & 3.83 & $33.14 *$ & 10.15 & 8.16 & 4.28 & 3.59 & $39.72 *$ \\
\hline Post-offering & 9.67 & 7.77 & 6.87 & 4.10 & 1.45 & 10.49 & 8.22 & 5.75 & 3.71 & $3.43 *$ \\
\hline Changes & 0.21 & -0.13 & 2.38 & 0.23 & & 0.33 & -0.01 & 1.47 & 0.05 & \\
\hline t-statistic & 1.67 & & 1.24 & & & $2.37 *$ & & 1.07 & & \\
\hline
\end{tabular}

* Statistical significance at the 0.05 level; ** statistical significance at the 0.10 level

As a robustness check, we also compare turnover ratios of issuing and matching funds to ensure the previous results are not driven by the fact that equity and international funds tend to have higher turnover. In Table 2 , we compute the difference in turnover ratios between the issuing and matching funds around fund offerings. Specifically, we find that issuing funds generate significantly more trading in the 6-month period prior to the offering than their non-issuing matching funds. In the six month period leading to the offering, issuing funds generate, on average, $1.67 \%$ more monthly trading than matching funds. This has been observed across all fund categories and such pattern is non-existent in the post-offering period. We interpret the increased trading in the preoffering period reflects intensified information asymmetries for the issuing funds.

Table 2: Turnover Ratio Difference between Issuing and Match Funds

\begin{tabular}{|c|c|c|c|c|c|c|}
\hline & \multicolumn{3}{|c|}{ All firms } & & & \\
\hline Diff. in turnover & Mean & Median & t-statistic & & & \\
\hline Pre-offering & 1.67 & 1.08 & $3.92 *$ & & & \\
\hline \multirow[t]{2}{*}{ Post-offering } & -0.37 & -0.31 & -0.55 & & & \\
\hline & \multicolumn{3}{|c|}{ Equity funds } & \multicolumn{3}{|c|}{ Debt funds } \\
\hline Diff. in turnover & Mean & Median & t-statistic & Mean & Median & t-statistic \\
\hline Pre-offering & 1.87 & 1.18 & $3.38 *$ & 1.21 & 0.76 & $2.01 *$ \\
\hline \multirow[t]{2}{*}{ Post-offering } & 0.62 & 0.37 & 1.19 & -2.69 & -1.16 & -1.46 \\
\hline & \multicolumn{3}{|c|}{ International funds } & \multicolumn{3}{|c|}{ Domestic funds } \\
\hline Diff. in turnover & Mean & Median & t-statistic & Mean & Median & t-statistic \\
\hline Pre-offering & 2.13 & 1.62 & $3.05 *$ & 1.13 & 0.76 & $2.67 *$ \\
\hline Post-offering & 0.54 & -0.32 & 0.8 & -1.46 & -0.24 & -1.18 \\
\hline
\end{tabular}

\section{Asset Market Timing}

Equity Market Timing vs. Asset Market Timing

Asset market timing is different from equity market timing, the type widely studied in the past. Asset market timing describes issuances triggered by favorable asset market conditions. Specifically, when asset market prices are low, issuing firms can use the proceeds from issuance to finance new asset purchase. This form of market timing aims to time the issuance to exploit temporary pricing inefficiencies in the asset markets while equity market timing acts to take advantage of equity pricing errors. 
We first verify whether these two types of market timing are present with closed-end fund issuers. Graph 1 illustrates the premium movement for fund issuers within one year surrounding the offering. We observe obvious equity market timing with equity and international funds. Equity and international issuers seem to issue at the end of a period of increased premiums that is then followed by a period of large declines in the overall market immediately after the issuance. In contrast, debt and domestic funds lack such a timing pattern. This result shows that market timing seems to be limited to funds that have more information asymmetries.

\section{Graph 1: Trading Premium for Closed-end Fund Issuers - Six Months before and after the Offering Month}

\section{Equity vs. debt closed-end funds}

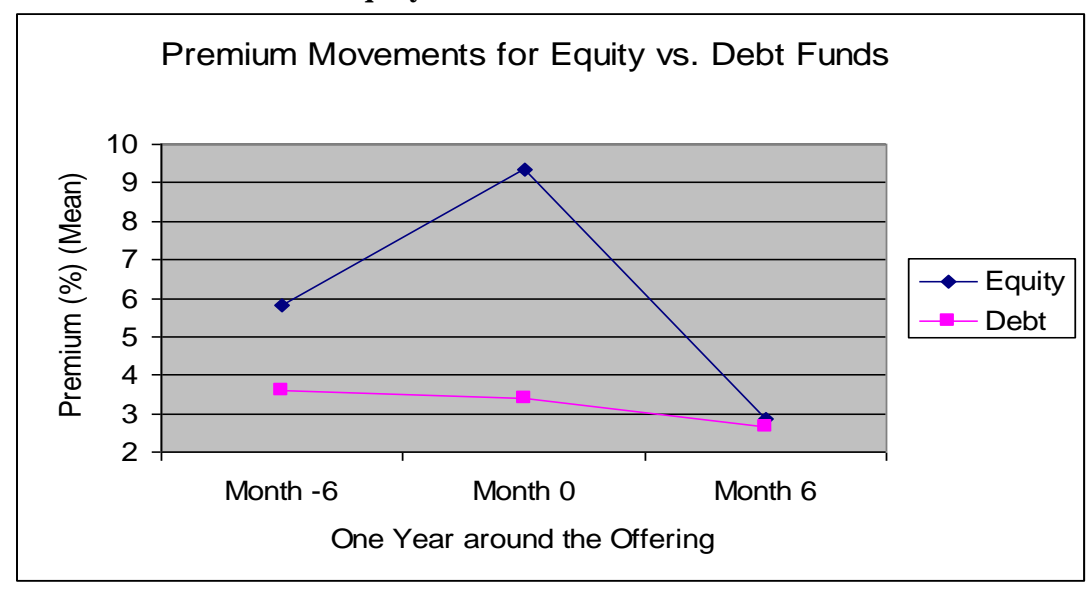

International vs. domestic closed-end funds

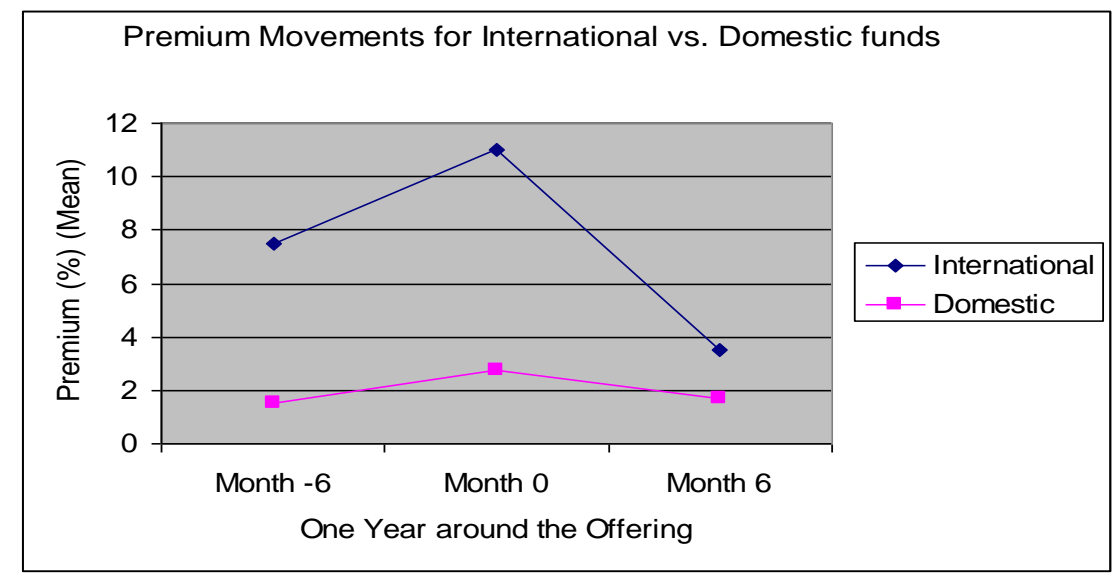

To test whether asset market timing actually exists, we first find a market index appropriate for each issuing fund. The choice of the market index is determined by the primary investment of the issuing fund. For example, the S\&P500 Index is selected for general equity funds and Moody's "Baa" is the choice for medium grade bond funds. For international funds, we match with country or area specific indices. ${ }^{1}$ We collect the prices of selected market indexes from 12 months before the offering to 6 months afterwards. Graph 2 plots the asset market movements surrounding the closed-end fund SEOs based on fund types. Setting the asset market return in the

\footnotetext{
${ }^{1}$ Data sources range from the Federal Reserve website to general finance websites such as Yahoo! Finance. Publications such as The Wall Street Journal and Dow Jones Indexes are also used.
} 
offering month as zero, we compute cumulate mean changes in asset markets from 12 months prior to and 6 months after the offering month.

Between equity and debt issuers, debt issuers are better asset market timers. In the 12 months leading to the offering, overall debt markets (proxied by different market indexes) tend to underperform and consequently debt instruments become 'undervalued'. The market timing of debt funds is illustrated by the observation that new shares are issued when asset markets approach the lowest. If we assume that the issuing proceeds are invested immediately following the offering, debt funds will tend to purchase inexpensive bonds that will improve in price as the asset market turns around shortly after the offering. The degree of price improvement varies across fund types, but the consensus is that debt markets overall stop the 'undervalued' trend due to the timing behavior of debt funds.
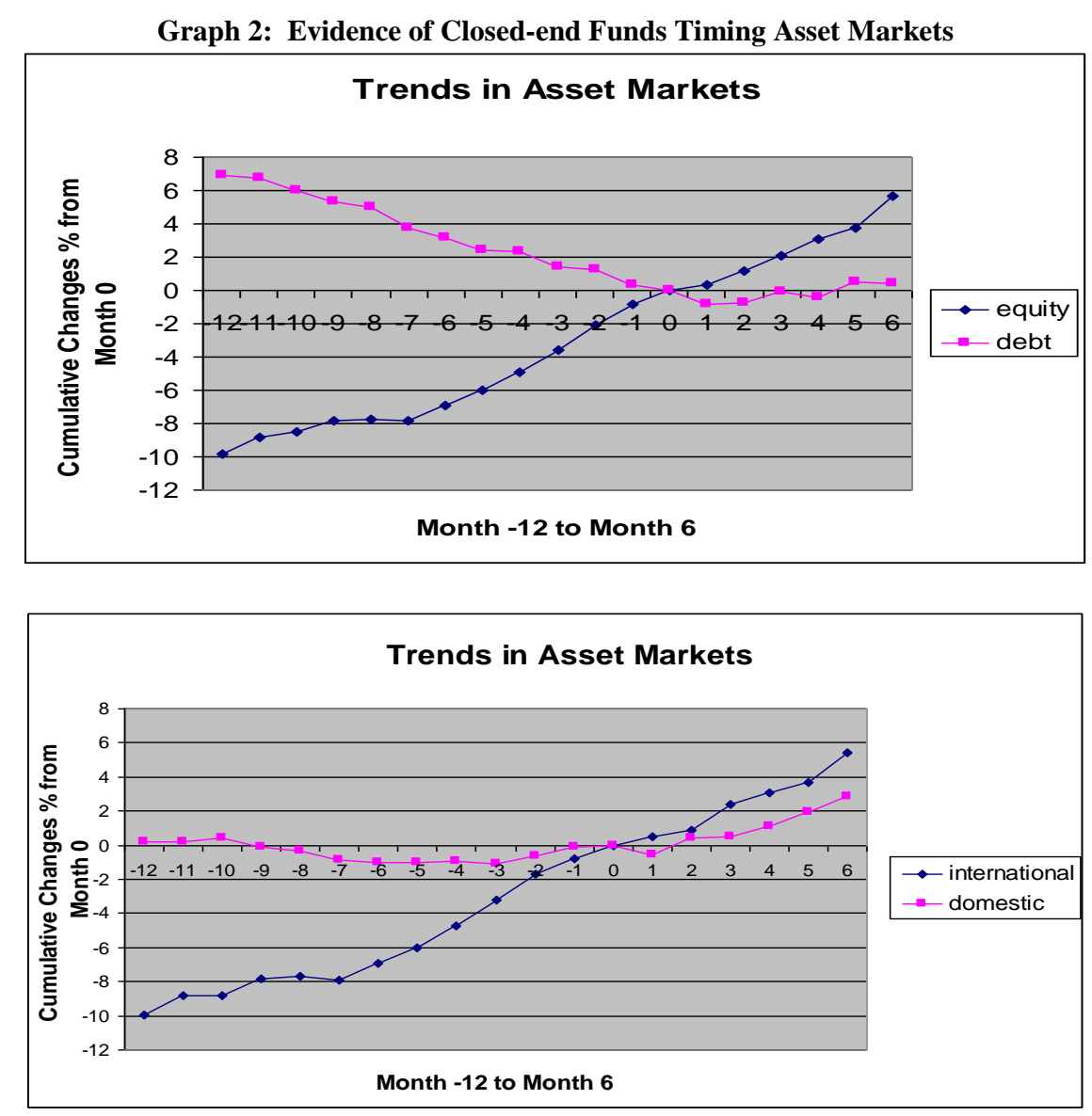

For the average equity fund, the offering clusters around a peak in the asset market, which makes any new investment more costly. Though the equity asset markets overall seem to increase in value across the sample period, the post-offering advance is not as large as the prior period. Compared to debt funds, equity funds are clearly poor market timers and making more expensive investment at the cost of the new fund investors. Similar evidence is found when international and domestic funds are compared. International funds are poor asset market timers. Domestic funds appear to issue and invest before the asset market takes off.

We conduct a proportions test to examine whether market timers are equally distributed across fund types with the results reported in Table 3. We categorize funds as good asset market timers if the offerings coincide with a downward movement in the asset market. Specifically, if the pre-offering average index value exceeds the average 
post-offering index value, the offering fund is defined as a good market timer. ${ }^{2}$ In Panels A, B and C of Table 3, we present results of the proportion tests for debt and equity funds. In Panel A, we show that $70 \%$ of debt issuers are identified as asset market timers based on our measure and only $29 \%$ of equity issuers behave like asset market timers. The difference between these two proportions is significantly different from zero based on the Chi-square test, Fisher's exact test and the Cochran-Mantel-Haenszel test. We control for domestic and international funds in Panel B and Panel C and find similar results.

As shown in panel D, E, and F, we are unable to find significant differences in proportions of asset market timers in international and domestic funds. In Panel D, 47\% of domestic issuers are market timers, and $34 \%$ of international issuers are market timers. The difference is not significant. In panel $\mathrm{E}$ and $\mathrm{F}$, we control for debt and equity funds, and the difference in proportions of market timers virtually disappears. We conclude that asset market timing is primarily practiced in debt markets, both domestic and international.

Table 3: Evidence of Closed-end Funds Timing Asset Markets across Fund Types

This table presents results of proportion tests for market timers across four fund categories. A closed-end fund is considered a market timer if the offering coincides with a downward movement in the underlying asset market. For each fund issuer, an appropriate asset market index is selected and index values in the pre- and post-offering are collected. Market timers are funds that issue when the pre-offering average index value exceeds the post-offering index value. Alternative methods to define market timers are tried and similar results are obtained. P-values for Chi-square test, Fisher's Exact Test and Cochran-Mantel-Haenzel Test are reported. Proportion tests are conducted between equity and debt closed-end funds with results in Panels B and C after controlling for domestic and then international classifications respectively.

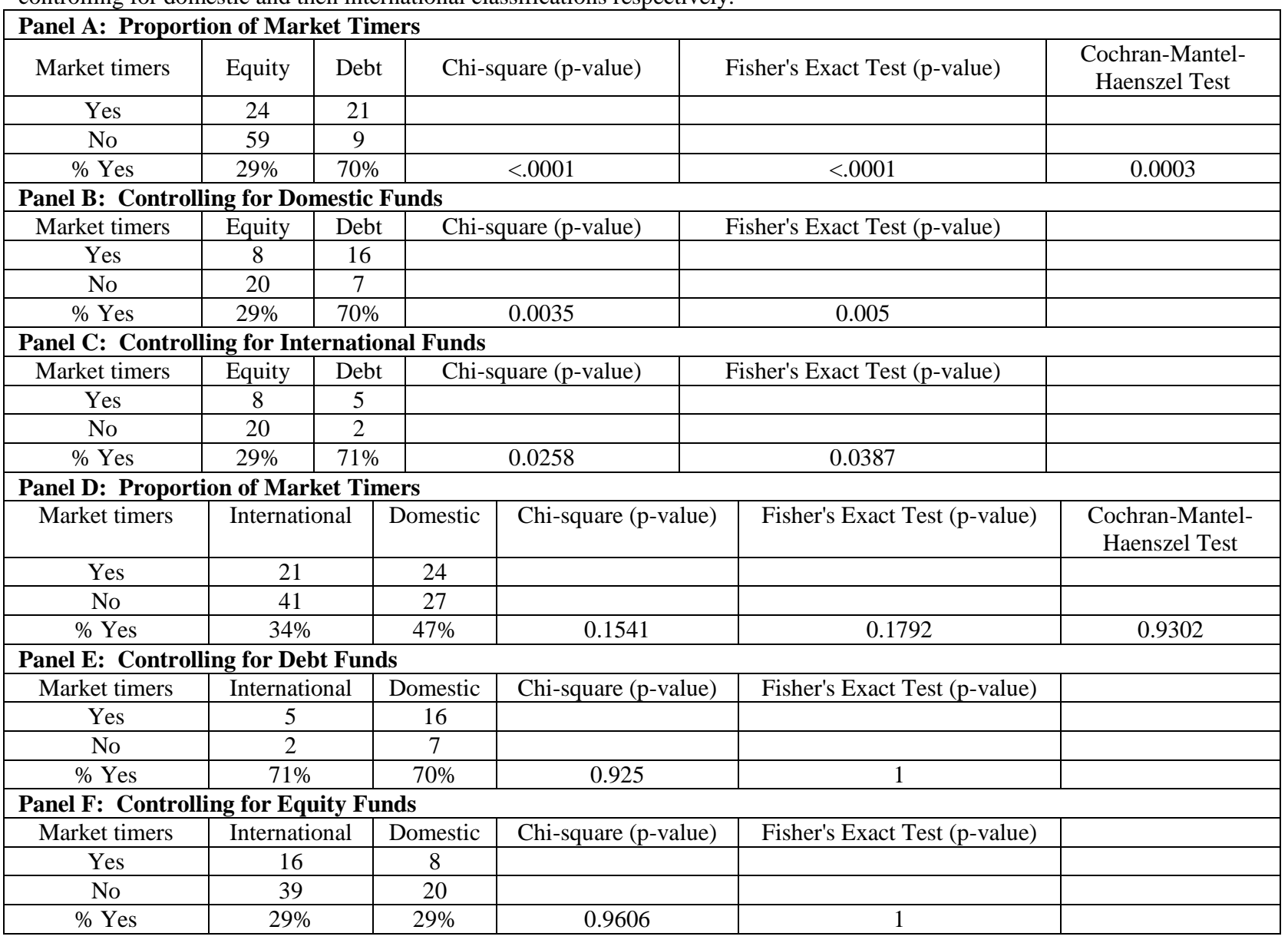

${ }^{2}$ Alternative methods to define market timers are used and similar results hold. 


\section{Asset Market Timing and Long-Run Fund Returns}

Knowing that debt issuers are good asset market timers, we want to verify whether this type of market timing generates better long-run returns. Table 4 presents unadjusted and adjusted holding period returns for closedend fund issuers from 1980 to 2004. Adjusted returns are obtained by using the average return of the match funds corresponding to each issuing fund as a benchmark. The two- and three-year post-offering return calculation uses a smaller sample due to data availability for fund offerings in 2003 and 2004. In the post-offering years, while equity fund issuers suffer significantly negative adjusted returns, debt fund issuers generate either significantly positive returns (10.714\% for the two years following the offering) or insignificant returns. Between international and domestic fund issuers, since we have not detected any significant difference in their ability to time asset markets, we equally expect no significant difference in their post-offering long-run returns. Both types generate insignificant returns with one exception. International funds, similar to equity funds, realize significantly negative returns in the 3 years following the offering. As shown previously, international and equity funds are good equity market timers and they take advantage of information asymmetry in the equity market to exploit the interest of new investors. As in the case of industrial firms, information-asymmetry driven issuers experience significantly negative long-run performance.

Table 4: Long-run Holding Period Returns across Fund Types

\begin{tabular}{|c|c|c|c|c|c|c|c|c|}
\hline \multirow[b]{2}{*}{ Sample } & \multirow[b]{2}{*}{ Prior year } & \multicolumn{4}{|c|}{$\begin{array}{c}\text { Unadjusted Holding Period Returns } \\
\text { (Sample Size) }\end{array}$} & \multicolumn{3}{|c|}{$\begin{array}{c}\text { Adjusted Holding Period Returns } \\
\text { (Sample Size) }\end{array}$} \\
\hline & & $\begin{array}{c}1 \text { year } \\
\text { post }\end{array}$ & $\begin{array}{c}2 \text { years } \\
\text { post }\end{array}$ & $\begin{array}{c}3 \text { years } \\
\text { post }\end{array}$ & $\begin{array}{c}\text { Prior } \\
\text { year }\end{array}$ & 1 year post & 2 years post & $\begin{array}{c}3 \text { years } \\
\text { post }\end{array}$ \\
\hline All & $\begin{array}{c}22.862 \% * \\
(126)\end{array}$ & $\begin{array}{c}2.851 \% \\
(129)\end{array}$ & $\begin{array}{c}7.075 \% * \\
(121)\end{array}$ & $\begin{array}{c}8.651 \% * \\
(118)\end{array}$ & $\begin{array}{c}3.420 \% \\
(90)\end{array}$ & $\begin{array}{c}-1.465 \% \\
(87)\end{array}$ & $\begin{array}{c}-3.031 \% \\
(79)\end{array}$ & $\begin{array}{l}-6.528 \% * * \\
(77)\end{array}$ \\
\hline $\begin{array}{l}\text { Equity } \\
\text { funds }\end{array}$ & $\begin{array}{l}28.052 \% * \\
(89)\end{array}$ & $\begin{array}{c}0.282 \% \\
(87)\end{array}$ & $\begin{array}{c}3.704 \% \\
(84)\end{array}$ & $\begin{array}{c}3.328 \% \\
(82)\end{array}$ & $\begin{array}{c}4.566 \% \\
(63)\end{array}$ & $\begin{array}{c}-3.736 \% * * \\
(60)\end{array}$ & $\begin{array}{c}-8.336 \% * \\
(57)\end{array}$ & $\begin{array}{c}-12.311 \% * \\
(55)\end{array}$ \\
\hline $\begin{array}{l}\text { Debt } \\
\text { funds }\end{array}$ & $\begin{array}{l}10.378 \% * \\
(37)\end{array}$ & $\begin{array}{c}8.170 \% * \\
(42)\end{array}$ & $\begin{array}{l}14.728 \% * \\
(37)\end{array}$ & $\begin{array}{l}20.777 \% * \\
(36)\end{array}$ & $\begin{array}{l}0.748 \% \\
(27)\end{array}$ & $\begin{array}{c}3.582 \% \\
(27)\end{array}$ & $\begin{array}{l}10.714 \% * * \\
(22)\end{array}$ & $\begin{array}{c}7.928 \% \\
(22)\end{array}$ \\
\hline $\begin{array}{l}\text { International } \\
\text { funds }\end{array}$ & $\begin{array}{c}29.956 \% * \\
(74)\end{array}$ & $\begin{array}{c}0.137 \% \\
(71) \\
\end{array}$ & $\begin{array}{c}2.578 \% \\
(70) \\
\end{array}$ & $\begin{array}{c}-1.570 \% \\
(70) \\
\end{array}$ & $\begin{array}{c}7.037 \% * \\
(51)\end{array}$ & $\begin{array}{c}-2.583 \% \\
(47) \\
\end{array}$ & $\begin{array}{c}-3.094 \% \\
(46) \\
\end{array}$ & $\begin{array}{c}-11.346 \% * \\
(46)\end{array}$ \\
\hline $\begin{array}{c}\text { Domestic } \\
\text { funds }\end{array}$ & $\begin{array}{c}12.766 \% * \\
(52)\end{array}$ & $\begin{array}{c}6.172 \% * \\
(58) \\
\end{array}$ & $\begin{array}{c}13.247 \% * \\
(51)\end{array}$ & $\begin{array}{c}23.559 \% * \\
(48)\end{array}$ & $\begin{array}{c}-1.308 \% \\
(39) \\
\end{array}$ & $\begin{array}{c}-0.152 \% \\
(40)\end{array}$ & $\begin{array}{c}-2.943 \% \\
(33) \\
\end{array}$ & $\begin{array}{c}0.620 \% \\
(31) \\
\end{array}$ \\
\hline
\end{tabular}

Asset Market Timing and Long-term Investors

Given that asset market timers are primarily debt funds, we expect that such funds are more likely to attract long-term investors. Investor trading horizon can be captured by turnover ratio according to Froot, Perold and Stein (1992). We verify that debt funds indeed have significantly lower turnover ratio than that of equity funds, as previously shown in Table 1 . The average turnover ratio of debt funds is $1 / 3$ to $1 / 2$ of that of equity funds around the issuance.

\section{Robustness Check: Regression Results}

We use a regression framework to examine the extent to which information asymmetry, proxy by turnover ratio, explains the short-term and long-term market responses to the closed-end fund seasoned offerings. We include the premium/discount immediately prior to the issue (PREM), the average turnover ratio within six months prior to the issue (PRETO), and the change in NAV immediately surrounding the issue (DIFFNAV). For both the short-run and long-run return regressions, we include the one-year pre-issue return (PRERET) to account for the possibility of price reversals explaining the long-run returns. Finally, for the long-run return regressions we include the announcement date abnormal return (ABRET) in order to control for potential over- or under- reaction to the issuance. Our independent variables include ABRET to examine the short-term market responses and then one-year, two-year and three-year post offering holding period returns (POSTAR1, POSTAR2 and POSTAR3) to examine the long-term market responses to the offerings. 
Table 5: Determinants of Short-run and Long-run Returns

Panel A: Regression Results for Equity Fund

\begin{tabular}{|c|c|c|c|c|c|c|c|}
\hline 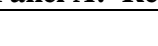 & \multicolumn{6}{|c|}{ Regression Coefficients } & \multirow[b]{2}{*}{ R-Squared } \\
\hline $\begin{array}{c}\text { Indep. } \\
\text { Variable }\end{array}$ & Intercept & DIFFNAV & PRERET & PRETO & PREM & ABRET & \\
\hline $\begin{array}{l}\text { ABRET } \\
(\mathrm{N}=81)\end{array}$ & 0.019 & 0.001 & 0.001 & $-0.001 *$ & -0.014 & & 0.096 \\
\hline $\begin{array}{c}\text { POSTAR1 } \\
(\mathrm{N}=76)\end{array}$ & 0.083 & $0.123 *$ & -0.122 & 0.004 & -0.125 & -2.083 & 0.191 \\
\hline $\begin{array}{c}\text { POSTAR2 } \\
(\mathrm{N}=74)\end{array}$ & 0.134 & $0.124 *$ & $-0.235^{*}$ & -0.004 & -0.027 & $-3.395 * *$ & 0.163 \\
\hline $\begin{array}{c}\text { POSTAR3 } \\
(\mathrm{N}=72)\end{array}$ & 0.070 & $0.122 *$ & 0.001 & $-0.012 * *$ & 0.049 & -1.954 & 0.147 \\
\hline
\end{tabular}

Panel B: Regression Results for Debt Funds

\begin{tabular}{|c|c|c|c|c|c|c|c|}
\hline \multicolumn{1}{|c|}{ Regression Coefficients } & PBRET & R-Squared \\
Variable & Intercept & DIFFNAV & PRERET & PRETO & PREM & ABRE \\
\hline $\begin{array}{c}\text { ABRET } \\
(\mathrm{N}=29)\end{array}$ & -0.002 & 0.001 & 0.007 & $-0.001^{*}$ & 0.000 & 0.018 \\
\hline $\begin{array}{c}\text { POSTAR1 } \\
(\mathrm{N}=29)\end{array}$ & $0.846^{*}$ & 0.056 & 0.234 & 0.012 & $-0.851^{*}$ & -0.356 & 0.263 \\
\hline $\begin{array}{c}\text { POSTAR2 } \\
(\mathrm{N}=25)\end{array}$ & $1.057^{* *}$ & 0.074 & 0.147 & 0.033 & $-1.065^{* *}$ & 5.334 & 0.251 \\
\hline $\begin{array}{c}\text { POSTAR3 } \\
(\mathrm{N}=25)\end{array}$ & 0.816 & -0.014 & 0.271 & 0.033 & -0.805 & 4.532 & 0.171 \\
\hline
\end{tabular}

Panel C: Regression Results for International Funds

\begin{tabular}{|c|c|c|c|c|c|c|c|}
\hline & \multicolumn{6}{|c|}{ Regression Coefficients } & \multirow[b]{2}{*}{ R-Squared } \\
\hline $\begin{array}{c}\text { Indep. } \\
\text { Variable }\end{array}$ & Intercept & DIFFNAV & PRERET & PRETO & PREM & ABRET & \\
\hline $\begin{array}{l}\text { ABRET } \\
(\mathrm{N}=70)\end{array}$ & 0.025 & 0.002 & 0.004 & $-0.001 *$ & -0.175 & & 0.105 \\
\hline $\begin{array}{l}\text { POSTAR1 } \\
(\mathrm{N}=66)\end{array}$ & 0.198 & $0.174 *$ & -0.097 & 0.004 & -0.241 & -2.444 & 0.232 \\
\hline $\begin{array}{c}\text { POSTAR2 } \\
(\mathrm{N}=65)\end{array}$ & 0.344 & $0.224 *$ & -0.243 & -0.005 & -0.209 & -3.069 & 0.232 \\
\hline $\begin{array}{c}\text { POSTAR3 } \\
(\mathrm{N}=65)\end{array}$ & 0.216 & $0.254 *$ & 0.029 & -0.010 & -0.142 & -1.739 & 0.223 \\
\hline
\end{tabular}

Panel D: Regression Results for Domestic Funds

\begin{tabular}{|c|c|c|c|c|c|c|c|}
\hline & \multicolumn{6}{|c|}{ Regression Coefficients } & \multirow[b]{2}{*}{ R-Squarec } \\
\hline $\begin{array}{c}\text { Indep. } \\
\text { Variable }\end{array}$ & Intercept & DIFFNAV & PRERET & PRETO & PREM & ABRET & \\
\hline $\begin{array}{l}\text { ABRET } \\
(\mathrm{N}=40)\end{array}$ & 0.008 & 0.001 & -0.020 & $-0.002 *$ & 0.000 & & 0.146 \\
\hline $\begin{array}{c}\text { POSTAR } 1 \\
(\mathrm{~N}=39)\end{array}$ & $0.621 *$ & 0.044 & -0.023 & -0.008 & $-0.515^{*}$ & -0.396 & 0.137 \\
\hline $\begin{array}{c}\text { POSTAR2 } \\
(\mathrm{N}=34)\end{array}$ & 0.439 & -0.089 & 0.275 & -0.024 & -0.263 & -2.250 & 0.150 \\
\hline $\begin{array}{c}\text { POSTAR3 } \\
(\mathrm{N}=32)\end{array}$ & $1.329 *$ & 0.008 & -0.379 & $-0.046^{* *}$ & -0.835 & -2.927 & 0.249 \\
\hline
\end{tabular}

Regression results for the four fund types are presented in Table 5. For international, domestic and equity funds, announcement day abnormal returns seem to be significantly inversely related to pre-offering turnover ratio at the 5\% level. Funds with higher turnover ratios tend to have lower announcement day abnormal returns. In the framework of information asymmetry, issuers with more information asymmetries should have worse market reactions. These regression results provide additional support for our interpretation that turnover ratio is a good proxy for information asymmetry. 
The ability of the turnover ratio measure to explain long-term market response is slightly mixed. For equity fund issuers, an example of good equity market timers, the higher the turnover ratio, the lower the post-offering 3year returns. For debt funds, an example of good asset market timers, there is no significant relation detected between turnover ratio and long-run returns. This is consistent with our argument that information asymmetry does not play a significant role in the equity offerings of debt funds.

There are other explanatory variables that are occasionally significant in explaining abnormal returns. The evidence is rarely consistent among the several measures of returns, so we refrain from providing any analysis.

\section{CONCLUSIONS}

In this study, we extend the previous research on whether and how information asymmetry explains the decision to issue seasoned offerings among closed-end funds. Although closed-end funds operate with marketable securities and presumably suffer fewer information asymmetries, there still exists a possibility that there might be large variation in information asymmetry across fund types. The source of the potential variation is related to the different security choices. Some securities are harder to price than others, so funds investing in these securities may present a harder valuation case for potential fund investors.

Using turnover ratio as an alternative measure of information asymmetry, we are able to show that equity and international funds suffer more information asymmetry and thus their issuing decision is primarily driven by information asymmetry. Similar to industrial issuers, they report long-term underperformance. In contrast, debt and domestic issuers suffer less information asymmetry. Instead of timing equity markets, they choose to time the underlying asset markets. This is a form of market timing benefiting both existing and new investors as it maximizes the long-run performance of the issuing funds. We show that both debt and domestic funds time their issuance when the asset markets are relatively underpriced. This pattern is particularly stronger for debt fund issuers. A proportion test also confirms that a large majority of debt fund issuers are asset market timers.

In addition, by interpreting turnover ratio as a measure of investor trading horizon, we also confirm that debt and domestic funds, by timing asset markets, are favored by long-term investors.

\section{AUTHOR INFORMATION}

Eric Higgins is Professor of Finance and von Waaden Chair of Investment Management at Kansas State University, where he also serves as department head. He works in areas of market efficiency, bank efficiency and security return patterns. His publication is seen in Financial Review, Journal of Real Estate Portfolio Management, Journal of Business Finance and Accounting and many others. Email: ehiggins@ksu.edu

Shawn Howton is Associate Professor of Finance in the Villanova School of Business at Villanova University, where he is also the Director of the Daniel DiLella Real Estate Center. He works in the areas of corporate governance and socially responsible investing as well as real estate. Email: shawn.howton@villanova.edu.

Shelly Howton is Associate Professor of Finance in the Villanova School of Business at Villanova University. She works in the areas of real estate, social responsibility and corporate governance and has also published in the area of security issuances. Email: shelly.howton@villanova.edu.

Sophie Xiaofei Kong is Assistant Professor of Finance at Western Washington University. Her research interests include mutual fund governance, closed-end funds, market misevaluation and corporate investment. She has previously published at Journal of Financial Research and Journal of Portfolio Management. Email: Sophie.Kong@wwu.edu 


\section{REFERENCES}

1. Akhigbe, A. and J. Madura, 2001, Motivation and performance of seasoned offerings by closed-end funds, The Financial Review 36, 101-122

2. Eckbo, E. and R. Masulis, 1992, Adverse selection and the rights offer paradox, Journal of Financial Economics 32, 293-332.

3. Froot, K.A., A.F. Perold, and J.C. Stein, 1992, Shareholder Trading Practices and Corporate Investment Horizon, The Continental Bank Applied Corporate Finance 5(2), 42.

4. Hansen, R., 1988, The demise of the rights issues, Review of Financial Studies 1, 289-309.

5. Higgins, E., S. Howton and S. Howton, 2002, Information transfers across same-sector funds when closedend funds issue equity, The Financial Review 37, 551-561.

6. Higgins, E., S. Howton and S. Howton, 2003, An analysis of closed-end fund seasoned equity offerings, Journal of Financial Research 26, 243-257.

7. Hong, H., T. Lim, and J. Stein, 2000, Bad news travels slowly: size, analyst coverage, and the profitability of momentum strategies, Journal of Finance 55, 265-295.

8. Khorana, A., S. Wahal and M. Zenner, 2002, Agency conflicts in closed-end funds: the c case of rights offerings, Journal of Financial and Quantitative Analysis 37, 177-200.

9. Kothare, M., 1997, The effects of equity issues on ownership structure and stock liquidity: a comparison of rights and public offerings, Journal of Financial Economics 43, 131-148.

10. Kyle, Albert S., 1985, Continuous auctions and insider trading, Econometrica 53, 1315-1336.

11. Llorente G., R. Michaely, G. Saar and J. Wang, 2002, Dynamic volume-return relation of

12. individual stocks, Review of Financial Studies 15, 1005-1047.

13. Loughran, T. and J. Ritter, 1995, The new issues puzzle, Journal of Finance 50, 23-51.

14. Myers, S. and N. Majuf, 1984, Corporate financing and investment decisions when firms have information that investors do not have, Journal of Financial Economics 13, 187-221.

15. Ritter, J, 1991, The long-run performance of initial public offerings, Journal of Finance 47, 3-27.

16. Schultz, P. 2003, Pseudo market timing and the long-run underperformance of IPOs, Journal of Finance 58(2), 483-518.

17. Wahal, S. and J.J. McConnell, 2000, Do institutional investors exacerbate managerial myopia? Journal of Corporate Finance 6(3), 307-329.

18. White, R. and P. Lusztig, 1980, The price effects of rights offerings, Journal of Financial and Quantitative Analysis 15, 25-40. 


\section{NOTES}

